\title{
Organic Certification: A Case Study of Organic Valley, Nepal
}

\author{
Sabita Aryal Khanna*, Lekendra Tripathee \\ Department of Environmental Science and Engineering, Kathmandu University, Dhulikhel, Nepal \\ Email address: \\ sabita@ku.edu.np(S. A. Khanna) \\ ${ }^{*}$ Corresponding author \\ To cite this article: \\ Sabita Aryal Khanna, Lekendra Tripathee. Organic Certification: A Case Study of Organic Valley, Nepal. International Journal of Applied \\ Agricultural Sciences. Vol. 4, No. 1, 2018, pp. 14-20. doi: 10.11648/j.ijaas.20180401.13
}

Received: November 13, 2017; Accepted: November 29, 2017; Published: January 11, 2018

\begin{abstract}
Organic agriculture is a holistic food production management system, which results in sound agroecological health, combat climate change, enhanced biodiversity and soil biological activities. There is an increasing interest in organic production all over the globe. With certification, there adds the confidence in the marketplace. Nepal government has authorized an organization called Organic Certification Nepal (OCN), who offers internationally accredited inspection and certification services to local operators. There are many other international organizations like NAASA (Australia), ECOCERT (France), One Cert Asia (USA), IMO (Switzerland), Control Union (Netherlands), CertAlletc. are also active in Nepal, with their agents. There are a number of methods to certify if a product is organic or not organic. This paper is an effort to find out potentials and development of organic agriculture and certification for hilly areas. Organic Valley which comprises of five VDCs out of which two VDCs is in Kavrepalanchok district and three VDCs is in Lalitpur district was surveyed by various means to assess the status of organic agriculture and certification. Through interaction with farmers, it was found $81.61 \%$ people are aware of organic farming while $68.96 \%$ are not aware of the organic certification. The major organic crop exported from the valley is coffee. Presently Internal Control System (ICS) found applicable for the certification of coffee. There is more scope of parallel cultivations in the valley, and that can be certified by using Participatory Guaranteed System (PGS). Organic farming is must since it improves environmental and human health, export possibilities and market place, discourage toxic chemical near human settlement, provide job space to youth and enhanced lifestyle.
\end{abstract}

Keywords: Organic Farming, Certifying Agencies, Accredited Inspector, ICS, PGS

\section{Introduction}

Nepal is an agricultural country and about $66 \%$ of people engaged in agriculture to sustain their livelihood and contributes about 33 percent to the GDP [1]. The practice of producing organic vegetables, fruit, milk, meat, fishes and their products also exists for more than ten years in some places of Nepal like Gamcha of Bhaktapur and Fulbari of Chitwan. Organic agriculture is a holistic production management system, which promotes and enhances agroecological health, including biodiversity, biological cycle and soil biological activities [2]. Harwood [3] outlines organic agriculture is a farming ways without the use of chemicals as it used to be done in 1940 's. There have not been any policies to restore this indigenous knowledge and agricultural practices so that it is not ignored, but also severely threatened to recover in many places [4]. Organic agriculture is a viable solution to preventing global hunger by providing comparatively higher yields from low input agriculture in food deficit regions [5]. Use of organic fertilizer proved to be given an excellent response as compared to inorganic fertilizer $[6,7]$.

Current practices of organic agriculture are a modification and continuation of indigenous practices [8]. Organic agriculture in Nepal was officially introduced by some professional, NGOs and individuals committed to the promotion of organic agriculture in small pocket areas. First NGO named Appropriate Alternative Agriculture (A3) was initiated in 1986 by Mrs Judith Chase in the support of organic farming and marketing. A systematic approach to promote organic agriculture was started in 1986 after the 
establishment of Institute of Sustainable Agriculture Nepal (INSAN) in 1986.

It was further accelerated by many organizations; most of them were involved in the movement of promoting organic agriculture. After 2002, the numbers of cooperatives and private initiatives have grown up considerably. As a result, production, productivity, availability and commerciality of organic agriculture production have been increasing day by day in Nepal. The International Federation of Organic Agriculture Movement (9) reported that 9789 ha of organic land $(0.23 \%$ percent of total agricultural land $)$ is managed by 1470 producers in Nepal.

About $26 \%$ of Nepalese farming systems are still not using the pesticides and chemical fertilizers in their farm [10] ironically only $0.02 \%$ of Nepalese area is declared as Organic area. There are about 26 organic farms registered 2005 covering about 45 ha of land while more than this land is estimated to be under organic farming practice as unregistered farms [11].

Some of the factors which have been affecting the food availability in Nepal are the limited arable land, depleting natural resource bases, increasing environmental-stresses, non-availability of environmentally sounds technologies. Lacks of the functional road, unavailability of irrigation water, disease and pest infestation on crops are major challenges to farmers bring organic production in commercial scale, besides marketing strategies, a technology of processing the harvest [12].

Organic Certification is a system of regulation designed to ensure organic producers and processors follow strict quality standards and accurately describe an environmentally sound production process. A certificate is a written guarantee issued by an independent certification agency and it officially states that the production processes or product complies with certain standards. Organic certification provides third party confirmation, thus there is added confidence in the market place. First, a product is grown in an organic production system that emphasizes plant and animal health, preventative management of pests, and judicious use of allowed materials. Then, the product is tracked and protected from contamination from the field to final sale, whether it is a raw agricultural commodity or a multi-ingredient processed product. The label may carry a claim of "100 percent organic," "Organic" (95\% to $100 \%)$ or "Made with organic ingredients" (at least $70 \%$ organic ingredients). There is requisite of buffer zone between organic and not organic fields, there suppose to be a transition period to claim organic production, all the parallel crops in a farm should be organic. First steps of organic certification are aselection of a certifier that can be International Foundation for Organic Agriculture (IFOAM), European Union (EU), Japanese Agricultural Standards (JAS), Biodynamic, GAP, Kosher, or Fair Trade. The second step can be application and submission of an organic systems plan (OSP), application and OSP Review by the Certifier then followed by an Organic inspection. According to NOP section 205.103 (b) (2), the Organic Standards specify that records must "fully disclose all activities and transactions in sufficient detail as to be readily understood and audited" (13). The check lists are comprehensive, and includes: crop production documentation checklist, field locations (maps), acreages, estimated yields, field history or land use documentation, field activity logs, input purchase/source records, input application records, seed, planting stock, and transplant records, audit trail documents, soil management activities, pest management activities, organic integrity, certification documentation, labels and labeling.

There are two different processes of organic certification one is called Participatory Guarantee Systems (PGS) and another is Internal Control System (ICS) prevailing in most of the organic farm. As Countries' political, economic and structural properties are important for agricultural credit systems [14] similarly organic certification system and procedure may vary from place to place.

PGS is based on IFOAM Standards and includes reference to social justice norms for organic practice. Participatory Guarantee Systems support and encourage producer and groups of the producer to work together and share their knowledge and experiences to improve their farming practices through the Transparency \& Horizontality. The guarantee system is created by the very farmers and consumers it serves, encouraging and sometimes requiring direct participation of farmers and consumers. Trust is created through open information and peer. Regionally Appropriate Participatory Guarantee Systems are specific to individual communities, geographic areas, cultural environments, and markets. They involve less administration and lower costs than export focused third party certification. Participatory Guarantee Systems can be used as a tool for improving local socioeconomic and ecological conditions by encouraging small-scale production and product processing. In local markets, they help smallholders to have their products recognized as organic. Networks between consumers and smallholders are enhanced and the impetus for smallholders to expand their production base is reinforced.

According to IFOAM, an Internal Control System (ICS) is the part of a documented quality assurance system that allows an external certification body to delegate the periodical inspection of individual group members to an identified body or unit within the certified operator. Third party certifications bodies have to inspect the wellfunctioning of the system, as well as to perform a few spotcheck re-inspections of individual smallholders [15]. There is a kit for smallholder groups and a kit for third party inspectors and certification bodies' personnel to records data. External Certification is very expensive and small farmers who have less land, especially in the mountainous and remote areas cannot afford the high cost due to the scale factors. But also certification is required not only for the marketing but also for the proper documentation, information, monitoring, etc to check whether the land is of required organic standards or not. The advantages of ICS can be, a majority of the task carried out by the farmers/groups and grass root level 
workers, the documents used in ICS helps in creating a very good database of Organic production and supply chain. Thus the process is lengthy not very clear to the farmers and cost becomes beyond the capacity of the grower.

\section{Objectives}

This study tries to find out the status of organic farming and certification issues in the context of the organic valley, a hilly tertian Nepal.

\section{Methods}

Data available in Government Department and NonGovernment Organization (NGOs) and (CBOs) are also revisited. Secondary Socioeconomic data are used and collected from the VDC Profile book. Biophysical and status of farming and the farmer's knowledge about organic farming and certification were collected as primary data in the field. Tools such as Focus group Discussion (in all five VDC) and Household survey (40\% of $\mathrm{HH})$ and key informants interview through questionnaires for data collection in Organic Valley. Interview was done with six key persons involved in organic certification in Nepal, they are Mr. Govinda Sharma (organic Inspector, OCN), Dr. Raju Raj Pandey (organic Inspector/Entomologist, ECOCERT), Dr. Bhaba Prasad Tripathee (Senior Associate scientistInternational Rice Research Institute, Nepal) and Dr. Krishna Prasad Paudyal (Scientist-Nepal Agriculture Research Council), Mr. Nabin Gopal Pradhan (Service and organic
growers-Fresh farm) and Mr. Bhim Khatri (NARC). The information thus collected were put together in Microsoft EXCEL and interpreted qualitatively.

\section{Study Area}

The research was done in Chamrangbesi Valley (Organic Valley, Durlung Valley). Chamrangbesi VDC lies in a southwest part of the district bordering Kavrepalanchok and Lalitpur District. Chamrangbesi is about $60 \mathrm{kms}$ from Kathmandu valley. Chamrangbesi VDC is located at south east of Kavrepalanchok District. More accurately it ranges around North $2730^{\prime} 00^{\prime \prime}$ to South $2724^{\prime} 30^{\prime \prime}$ and East $8528^{\prime}$ $00^{\prime \prime}$ to West $852^{\prime} 00^{\prime \prime}$. Chamrangbesi is at foothills of Mahabharata range.

The survey was done in 5 VDCs of the OrganicValley; they are Chamrangbesi VDC, Milche VDC, Thuladurlung VDC, Chandanpur VDC and Kaleshwor VDC. Out of these five VDCs, Chamrangsesi and Milche lies in Kavrepalanchok district and Thuladurlung, Chandanpur and Kaleshwor VDCs lies in Lalitpur district.

\section{Result and Discussion}

\subsection{Demography and Ethnicity}

Thuladurlung VDC has the highest number of households and has the highest population among the three VDCs mentioned in table 1 .

Table 1. Population of five VDCs of the Valley (2001 census) (Source VDC Profile).

\begin{tabular}{|c|c|c|c|c|c|c|c|}
\hline S. $\mathbf{N}$. & $\begin{array}{l}\text { Name of VDCs In Lalitpur } \\
\text { district }\end{array}$ & Average House Hold size & Total no. of House hold & Total Population & Male & Female & Total \\
\hline 1. & Chandanpur & 5.85 & 209 & 1223 & 637 & 586 & 1223 \\
\hline 2. & Kaleshwor & 5.68 & 285 & 1618 & 805 & 813 & 1618 \\
\hline 3. & Thuladurlung & 5.54 & 327 & 1811 & 897 & 914 & 1811 \\
\hline 4. & Chamrangbesi & 6.21 & 295 & 1833 & 918 & 915 & 1833 \\
\hline \multirow[t]{2}{*}{5} & Milche & 6.1 & 434 & 2647 & 1316 & 1331 & 2647 \\
\hline & & & & & & Total & 9,132 \\
\hline
\end{tabular}

Survey result shows, the majority of respondent are Bhramins (57\%) then followed by Tamang (34\%), Chetri (2\%), Dalit (2\%), Newar $(1 \%)$, Tharu $(1 \%)$ and others $(2 \%)$ in Organic Valley. which is almost synchronized with the inhabitation in this areas by ethnicity, where as Milche VDC the case is little different, the most dominating ethnic group is Tamang $(66 \%)$ followed by Bhramins (27\%), Dalit (5\%), Chetri (2\%).

\subsection{Occupation and Scope of Organic Farming}

Agriculture is the main occupation of the people living in the Organic Valley. $100 \% \mathrm{HH}$ are engaged in integrated farming with domestic animals like buffaloes, cows, goats, chickens etc in sloppy and terraced agricultural landscape. Khuwa (made from milk), meat, eggs, fishes etc are main cash earning products. Raring silkworms for silk and honey bees for honey are also practised here. Farm Yard Manure (FYM) is major fertilizer. The major cereal crops in the valley are maize, paddy, millet, wheat, barley etc. in the valley. Zinger, soya beans, beans, mustard, and other vegetables are also grown. The major cash crops in the valley are Coffee, oil seed, potato, broom grass etc. Coffee cultivation has become famous in most of the VDCs of the valley as it has helped to uplift the economy of the people in the area. The major fruits found in the valley and hills surrounding the valley are banana, mango, guava, peach, pineapple etc. Heavy prospects are seen in strawberry farming and mushroom cultivation. Amazing mountain covering wild strawberry and forest flavouring mushroom grows in the rainy season. Marketing is the major constraint. Collection and transportations of fresh vegetables and fruits are restricted due to bad roads. In Durlung some amount of vegetables, milk, khuwa, are sold in Chapagaun, Panauti and Banepa. Group of farmers collect their product and bring to market regularly. 


\subsection{Sensitisationof Organic Agriculture}

Most of the farmers were aware of the organic farming in the valley (out of 87 participants 71) people revealed that that the organic farming is the farming done without the use of chemicals; some replied that organic product is produced only using manure as a fertilizer source and some even said that the indigenous and traditional way of farming is organic farming. In Thuladurlung and Jhingedana organic coffee farming is practised and is supported by certification by coffee cooperatives. There is a strict restriction of chemical use for coffee production.

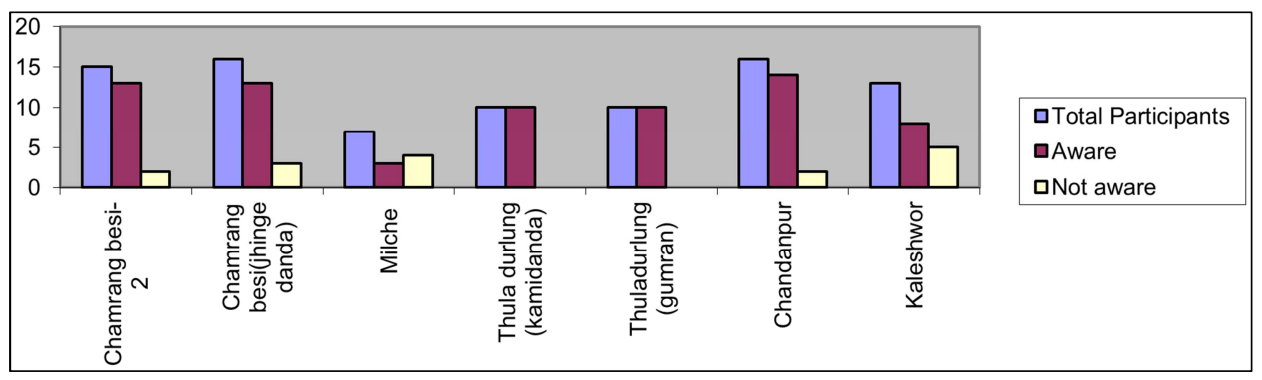

Figure 1. Awareness of organic farming

About the advantages and benefits of organic farming, most of the farmers are found to be goodknown. Some said that their cost for production is reduced as they don't have to buy the fertilizers. Some replied that organic products are healthy and they don't get diseases like cancer. Some said as organic farming is regular they realized the improvement of natural soil fertility; also helps in environmental protection and long-term production. Some people also told that with organic farming they get sustainable market and have possibilities to export their products in the international markets. People also think that if they go for organic farming they get paid high for their products.

\subsection{Status of Organic Farming in the Valley}

In Thuladurlung VDC in Lalitpur district, people became aware of organic agriculture after the establishment of Cope program under Helvetas Nepal. This program was established with an aim of producing organic coffee and people were trained with different practices of organic farming. Since 5 years back they have stopped using chemicals on their farm. They have also learnt about making fertilizers and pesticides from the available biological resources. Almost all people are doing organic farming and they are very much interested in this type of farming. In Chamrangbesi VDC, most of the people are doing organic farming now. Lately, some farmers were using some chemical fertilizers like Urea, DAP and MoP occasionally to combat disease and to enhanced production especially for potatoes and some other vegetables. Many farmers have stopped doing conventional farming and started going organic since 3 years in this VDC and others also wants to go for organic farming as well. Coffee farming is initiated by many farmers and making their farm organic. In Milche VDC, though farmers have very little knowledge about words and definitions of organic farming. Since it is remote area none of the chemical fertilizer ever reached there. They have just started coffee farming in the VDC and they were sure that their farm is organic and they too can sell coffee as done by a neighbouring village. People in Chandanpur VDC, are also aware of the organic farming.
Some people are practising no chemical farming but some are also using chemical fertilizers. The farmers said that they need trainingin organic farming in their village. They are willing to go for organic farming. In Kaleshwor VDC, only a few people have the knowledge of Organic farming. Almost all the people are using Urea for the production of maize and mustard. Some of them know about the harmful effects as hardening of soil due to use of chemicals, even though they are using as they told if they stop using chemicals, the productivity will decrease for 2-3 years. If some training is given and systematic knowledge on the organic farming system is given then the people are willing to go for organic farming.

As taking into account the status of farming in all the five VDCs we can say that the area can be easily converted into the Organic area. However, in a comparative report, it is also said it is easier in Thulodurlung as compared to Chamranbesi [12].

\subsection{Needs of Organic Certification}

Expert says certification is a need for the proof that the farm is totally organic. According to our key informants, certification is not necessary for Nepal for local markets, but for the Regional and national market, it is necessary. Dr Raju Raj Pandey said that it is important to protect the consumer right and prevent fraudulent products entering the market.

Organic certification is the demand of a market. If we are looking for export to USA, EU or Japan, organic products must be certified. However, Nepal government has passed the Nepalese organic standard but has not decided how the certification bodies will be accredited.

Dr Krishna Prasad Paudyal said that certification in Nepal is needed for the promotion of the product in the International markets. Certification is required for the proof that the product is organic. The important problem for the marketing of the products and trade of the products is that of certification. According to International Federation of Organic Farming Movement (2003), the number of an organic farm in Nepal is 26, and the area under Organic 
management is 45 hectare. However, the area under organic farming is much higher if considered the area under traditional farming where farmers never used fertilizers and pesticides. Therefore the farm and product should be certified and certification process is a must for the trust and overall marketing of the organic products.

Many of the rural areas can get the certificate of organic farm and the people can also raise their economy and increase the standard of living in rural areas as in most of the rural areas people are not been able to use chemical fertilizers on their farm. This may be due to lack of transportation and poor economy of the people according to Dr Bhaba Tripathee. Therefore certification is need of Nepalese people which can raise the economy as well as the standard of the people and good health of the nation can be obtained.

There are indeed different challenges and constraints ahead due to the weak enabling environment, lack of research information and marketing infrastructure. The certified product can improve the economic condition of the farmers as well as the whole country. The informants also told that if certification brings opportunities for protection of local resources, better market access, improvement of worker and consumer health and enhancement of living condition of rural communities.

As we can see from the graph that in Chamrangbesi VDCs very few people don't know about certification but in case of Milche VDC nobody have an idea about certification. In Thuladurlung VDC all people are aware of certification and in Chandanpur VDC also only a few are not aware. In case of Kaleshwor VDC, more than $50 \%$ people are not aware of certification.

Some people realized the benefits of their farm certified as organic. Most of the people said that certification processes to prove whether their farm is organic or not. They also said that certification is required for the International markets for their products. Thuladurlung VDC, their coffee farm is certified by NASAA-Australia by the process of Internal Control System (ICS). The Organic Agriculture Inspector has visited and inspected the area and is inspecting about the documents and going to certify the area time to time.

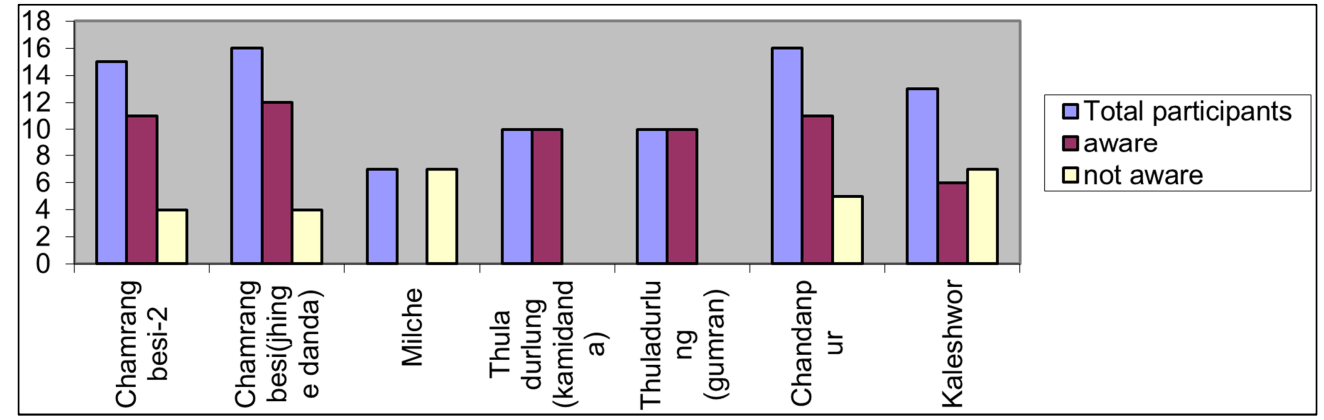

Figure 2. Awareness on Organic Certification.

The certification process can be easy in these areas as one VDC is certified already for coffee. On parallel to coffee, there is the scope of other organic cultivations, which can be certified by using Participatory Guaranteed System (PGS). Some special awareness program should be organized in Kaleshwor VDC, Lalitpur.

\subsection{The Process of Organic Certification Applied in Nepal}

Certification of Organic products was firstly introduced in 1996 in Nepal (16). There is only one national certification organization Organic Certification Nepal (OCN) and many international organizations such as NASAA (Australia), ECOCERT (France), One Cert Asia (USA), IMO (Switzerland), Control Union (Netherlands), Cert All, ICEA (Italy), ECOCERT (Belgium shows their presence in Nepal to work on Organic products certification. OCN (Organic Certification Nepal) is newly formed certification body formed for the organic certification and promotion of organic agriculture in Nepal. For the inspection purposes, Nepal Organic Inspectors Association (NORIA) has been formed in Nepal. Certification Alliance (Cert All) is a regional collaboration in certification representing national and international Organic Certification bodies, inspectors, producers and development organizations supporting organic movements in Nepal. Recently, Organic Certification Nepal $(\mathrm{OCN})$ is one of the founder members of Certification Alliance (Cert All). So, being linked with Cert All, OCN offers an internationally recognized inspection and certification services to local farms of Nepal and operators at a reasonable cost.

Certification methods can differ from one standard to another according to Dr Raju Raj Pandey. Different certifying bodies can follow their own operating rules to verify and assure the conditions mentioned in the standard. But the operating processes must be approved by the national/international accreditation body. According to $\mathrm{Dr}$ Bhaba Tripathee, the inspectors trained in different countries might follow different criteria for organic certification in Nepal and Dr Krishna Paudyal said that certification methods differ from organization to organization and rules and regulation of the country. According to Mr. Govinda Sharma normally the certification methods are not same but the overall system is the government of Nepal has suggested its own steps/process described in the standard. According to Mr Govinda Sharma, the first step is an application, second is a feasibility study, third is agreement and then inspection and at last certification. According to him these steps are developed through experiences of various certification agencies. 
NARC and IRRI still willing to do much research in the steps of the certification process for Nepal. According to thecost for the certification is quite expensive for a normal farmer of Nepal.

\subsection{Organic Farming and Nepalese Economy}

Different informants had different thoughts about Organic Farming will increase the economy. Mr Govinda Sharma said agriculture in Nepal is not been able to contribute much to the overall growth of the country till now being an agricultural country. It is because of less investment in science and technology, the involvement of uneducated people in farming, poor infrastructure in rural areas and corruption and malfunctioning of the government system. He said that organic farming can improve human health, environmental protection, export promotion and overall economic development. Organic practice is for farmer's health, then for the health of the consumers, community and environment. The economy is certainly important. The market should be created for products that are already organic in production or can easily be produced through organic practices and then gradually move to crops that require high external inputs. A country like ours has enormous natural resources that can be used to an organic lifestyle. However, making whole country organic is just a dream. A dream can come true but must work hard. $\mathrm{Mr}$ Nabin Gopal Pradhan said that Nepal has a diversified climate with different altitude which helps to produce organic farming. So it is relevant. We should go for it to protect microfauna and flora, maintain soil fertility, and to minimize pollution in the environment. Dr Bhaba point out less priority of government in agriculture, subsistence agriculture and commercial, less opportunity in agriculture for youth have not been able to give the fruit of agriculture in national development; he stressed, in our country, there is no chemical fertilizer factory and have to import from other countries. Therefore Nepal should give priority in organic farming and it is very much relevant to Nepal. According to Dr Raju, as the state has grossly neglected agriculture and farmers, agriculture in Nepal is not been able to contribute overall growth of the country. He stressed that organic farming has to be promoted based on higher price in the market. Poverty does not support organic movement, knowledge, and attitude. Mr Bhim Khatri also stressed that; our agriculture is traditional and not commercialized well. Therefore agriculture is not been able to contribute much as expected. Therefore going organic is fruitful for Nepalese farmers as well as consumers.

\section{Conclusion}

The study conducted in five particular VDCs showed that organic farming can be successful in such hilly farm, since Thuladurlung VDC is already certified as organic coffee farms. The growing attitude of chemicals free faming, integration of livestock, and top of it farmers' interest has added the prospect of organic farming in Chamrangbesi and other VDCs as well. Problems associated with irrigation and disease has restricted the farming in commercial scale. The results of the study also reveal organic agriculture sector still needs lots of research for organic solutions to problems of pest, diseases, evolve new varieties that can give comparable production under organic management. Government should give priority to organic agriculture by providing technical, logistic and other infrastructural support. With increase in awareness of good of organic products, customers also want certification for the products. Small and marginal farmers can't take the cost of certification, government and NGOs must provide support for the certification process and motivate the organic growers.

As a whole it can be concluded that Chamrangbesi valley can be converted into organic valley in less effort. It will be very easy to certify the valley as organic as the farmers are doing organic farming and others also wants to go for organic. Farmers in the valley should follow Internal Control System (ICS) for the certification process as it will be cheaper as well as effective for the small farmer's group. Participatory Guarantee System (PGS) can also be applied in the other products of Thuladurlung VDC for the certification as coffee is already certifies by NASAA-Australia.

\section{References}

[1] Ministry of Agricultural Development (MOAD), Nepal. Available at http://www.moad.gov.np/en/ Retrieved on 09-112017.

[2] FAO. (2002). Food safety and quality as affected by Organic farming. Food and Agriculture Organization. Available at http://www.fao.org/docrep/meeting/x4983e.htmal. Retrieved on 09-11-2017.

[3] Harwood, Richard R. 1990. "A history of sustainable agriculture." Ch. 1 in Clive Edwards, Rattan Lal, Patrick Madden, Robert H. Miller, and Gar House (eds.), Sustainable Agricultural Systems. Ankeny, IA: Soil and Water Conservation Society.

[4] Vaidya, B. (2006). The organic scenario in Nepal. Paper presented at the seminar of Organic Farming for Sustainable Development, Colombo, Srilanka.

[5] Leu, Andre F. (2004). Organic Agriculture Can Save the World. Well Being Journal 13 (2). Available a www.wellingbeingjournal.com/articles.html. Retrieved on 0911-2017.

[6] Muhammad Bilal, Muhammad Tayyab, Irfan Aziz, Abdul Basir, Bilal Ahmad, Umair Khan, Muhammad Zahid, Naveed Ali, Impact of Integrated Fertilization (Organic and InOrganic) on Grain Yield of Maize, Agriculture, Forestry and Fisheries. Vol. 6, No. 5, 2017, pp. 178-183. doi: 10.11648/j.aff.20170605.16.

[7] Bhaskarrao Chinthapalli, Dagne Tafa Dibar, D. S. Vijaya Chitra, Melaku Bedaso Leta. A Comparative Study on the Effect of Organic and Inorganic Fertilizers on Agronomic Performance of Faba Bean (Viciafaba L.) and Pea (Pisumsativum L.). Agriculture, Forestry and Fisheries. Vol. 4, No. 6, 2015, pp. 263-268. doi: 10.11648/j.aff.20150406.15. 
[8] Ibeawuchi I. I., Obiefuna J. C., Tom C. T., Ihejirika G. O., Omobvude S. O. Indigenous and Current Practices in Organic Agriculture in Nigeria: A Review. Agriculture, Forestry and Fisheries. Vol. 4, No. 6, 2015, pp. 257-262. doi: 10.11648/j.aff.20150406.14.

[9] International Federation of Organic Agriculture Movements (IFOAM, 2012). Organic Eprints. Available at http://www.ifoam.org. Retrieved on 09-11-2017.

[10] Sharma, Gobind., 2005. Organic Agriculture in Nepal: An Analysis in to Status, Policy, Technology and Psychology.” In: Sharma, G. and P. B. Thapa (Eds.) Proceedings of National Workshop on Organic Agriculture and Food Security, December 13-15, 2005, Kathmandu, Nepal.

[11] Shakya, D. B. (2005). Organic products: International market. In G. Sharma, P. Thapa (Eds.), Workshop on organic agriculture and food security. Proceedings. Kathmandu: Nepal Permaculture Group.
[12] Khanna Sabita Aryal (2016) Prospects of organic farming in hill farms of Nepal. Tropical Plant Research 3 (1): 70-77.

[13] National Organic Program (NOP). United States Department of Agriculture. Agricultural marketing service. Available at http:/www.ams.usda.gov/nop Retrieved on 09-11-2017.

[14] Gunes, E. and Movassaghi, H. (2017) Comparative Analysis of Agricultural Credit System and Organization in Selected Countries. International Journal of Applied Agricultural Sciences. Volume 3, Issue 5, September 2017, Page: 123-135.

[15] IFOAM. (2003). IFOAM's position on small holder group certification for organic production and processing, Submission to the European Union and Member States. Available at http://www.IFOAM.org. Retrieved on 09-112017. 